\title{
当科に和ける甲状腺疾患の臨床的検討
}

\author{
中村 正・青柳 優・木村 洋 \\ 小池 吉郎・加藤 功*
}

\section{A Clinical Study of 90 Cases of Thyroid Diseases}

\author{
Tadashi Nakamura, Masaru Aoyagi, Yo Kimura and Yoshio Koike \\ (Yamagata University)
}

Isao Kato

(St. Marianna University School of Medicine)

Between November, 1976 and December, 1990, 90 patients underwent surgical treatment for thyroid disease at our department. Fifty of these patients (55.6\%) were pathologically diagnosed as having malignant tumors (papillary carcinomas in 38 cases, follicular carcinomas in 6, squamous cell carcinomas in 3, aplastic carcinomas in 2 and malignant lymphoma in 1 case). The 40 other patients (44.4\%) were diagnosed as having benign diseases (adenomatous goiters in 13 cases, follicular adenomas in 13, thyroid cysts in 6 , papillary adenomas in 4 and other diseases in the remaining 4 cases). All 17 patients, in whom recurrent nerve paralysis was observed preoperatively, had malignant tumors of papillary carcinomas in 14 cases, squamous cell carcinomas in 2 cases and follicular carcinoma in 1 case.

${ }^{201} \mathrm{Tl}$ delayed scintigrams were obtained for 79 patients. Forty-seven of these patients $(59.5 \%)$ showed abnormal activity on the delayed scintigram and 34 out of 47 patients were pathologically diagnosed as having malignant tumors.

Total or subtotal thyroidectomy was performed in $80 \%$ of the patients with malignant tumors and radical or modified neck dissection was carried out in 23 cases in which the metastasis of cervical lymph node was recognized.

Eleven of our patients showed recurrent nerve paralysis after the operation. In 3 of these cases, the recurrent nerve was dissected because of direct invasion into this nerve. In 5 of the remaining 8 cases, complete recovery from recurrent nerve paralysis occurred within 6 months following the operation, while 2 cases retained incomplete paralysis of this nerve.

Key words: thyroid disease, surgical treatment, clinical study 
はじめに

近年，甲状腺疾患を扱ら耳鼻咽喉科施設が増 えつつあり，各施設に拈ける甲状腺疾患の臨床 統計の報告も散見されている1) 3)。我々も，昭 和51年 11 月耳鼻咽喉科病棟開設以来, 平成 2 年 12月現在までの約14年間で，90例に対して甲状 腺手術（初回手術のみ）を施行しているが，今 回は，これらの症例に対する臨床的考察を行い， 当院における現状及び問題点について報告する。

\section{対象症例}

昭和 51 年 11 月耳鼻咽喉科病棟開設以来, 当科 で手術を施行した症例総数5019例中，甲状腺手 術はのべ96例行われて挴り，そのらち初回手術 例は90例である。男性は18例，女性は72例で， 男女比は $1: 4$ 之, 女性が圧倒的に多い。年齢 構成を図 1 に示したが，年齢は 13 歳〜 81 歳と非 常に広い範囲にわたって拈り，その平均年路は 50.5歳であった. 女性は30～50歳代が最も多く, その平均年齢は49.1歳であった。男性は60歳代 にピークを示し, その平均年齢は56.2歳であり,

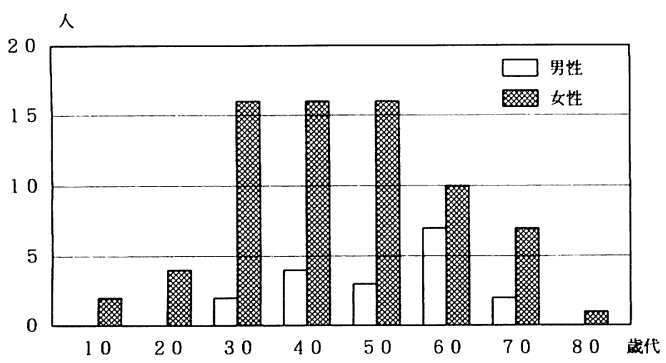

図 1 男女別症例数

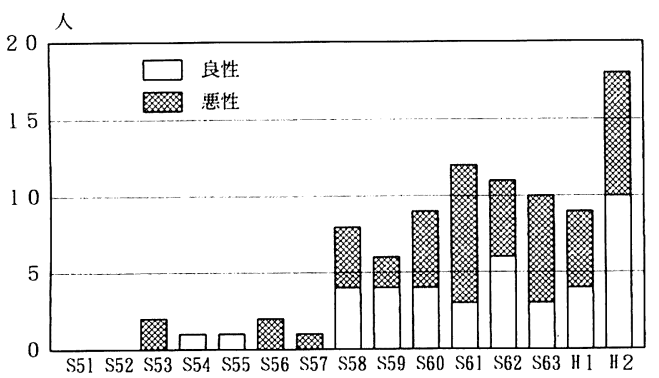

図 2 年次別症例数
男性の方が平均年齢が高い傾向にあった。

年次推移を図 2 に示した。昭和51年より昭和 57 年までの 7 年間は，年間数例程度の症例数で あったが，昭和58年より急激に手術症例が増加 し，昨年は年間18例と例年の約 2 倍の症例数で あった

以下，これらの症例について臨床的検討を行 った。

\section{1. 病理組織診断}

表 1 に，術後の病理診断の内訳を示した。良 性疾患は 90 例中 40 例 $(44.4 \%)$ ，悪性疾患は50 例（55.6\%）で，悪性疾患が若干多い傾向にあ る。良性疾患では，濾胞腺腫及び腺腫様甲状腺 腫が，良性疾患40例中それぞれ13例（32.5\%） と最も多く，次いで，甲状腺褧胞 6 例 (15.0\%), 乳頭腺腫 4 例，その他 4 例であった．悪性疾患 では，乳頭癌が，悪性疾患 50 例中 38 例 $(76.0 \%)$ と最も多く，次いで濾胞癌が 6 例 (12.0\%) で あった，未分化癌，悪性リンパ腫，扁平上皮癌 は，それぞれ 2 例， 1 例， 3 例と極少数であっ た。

悪性疾患の性別による割合をみると，男性で は18例中14例（77.8\%），女性では72例中36例 （50.0\%）と，男性の方が悪性率が高い傾向に ある、特に, 悪性リンパ腫, 扁平上皮癌は全例 男性であった。

表 1 病理組織別分類

\begin{tabular}{|c|c|c|}
\hline 病 理 & 組 織 & 症例数 \\
\hline \multirow{5}{*}{$\begin{array}{l}\text { 良 性 } \\
(40 \text { 例) }\end{array}$} & 濾胞腺腫 & 13 例 \\
\hline & 乳頭腺腫 & 4 \\
\hline & 腺腫様甲状腺腫 & 13 \\
\hline & 甲状腺囊胞 & 6 \\
\hline & その他 & 4 \\
\hline \multirow{5}{*}{$\begin{array}{l}\text { 悪 性 } \\
(50 \text { 例) }\end{array}$} & 乳頭癌 & 38 \\
\hline & 濾胞癌 & 6 \\
\hline & 未分化癌 & 2 \\
\hline & 悪性リンパ腫 & 1 \\
\hline & 扁平上皮癌 & 3 \\
\hline
\end{tabular}


2. 主 訴

表 2 に主訴の内訳を示した。頸部腫瘤を主訴 として来院した患者が最も多く48例（53.3\%） と約半数を占めている. 次いで嗄声を主訴とし た患者が20例 (22.2\%), 咽喉頭異常感が 8 例 （8.9\%）と続いている. 嗄声を主訴とした患者 のらち，1例を除き全例が悪性疾患であり，そ の内訳は17例が乳頭癌で, 濾胞癌, 扁平上皮癌 が各 1 例であった。

咽喉頭異常感を主訴とした患者は 8 例である が，そのらち 3 例が悪性疾患（乳頭癌 2 例, 濾 胞癌 1 例）であった. 甲状腺検診で甲状腺腫瘤 を指摘され，当科を受診した 3 例の患者は，そ の他の項目に含まれているが，これらは，全例 過去 1 年間の症例であり, このうちの 1 例は乳 頭癌であった. 残りの 9 例は, 他の耳鼻咽喉科 疾患で受診し, 初診時の頸部触診にて, 甲状腺 腫瘤を指摘された患者で, このらちの 3 例が乳 頭癌であった。

3. 訪医経路

表 3 に，当科を受診するまでの訪医経路につ いて示した．紹介患者が54例 $(60 \%)$, 当科初 診患者が36例（40\%）であり，6 割が他施設よ りの紹介患者である。これら紹介患者のうち，

表 2 主訴

\begin{tabular}{|c|c|c|c|}
\hline & 良 性 & 悪 性 & 計 \\
\hline 頸 部 腫 瘤 & 27 例 & 21 例 & 48 例 \\
\hline 声 & 1 & 19 & 20 \\
\hline 咽喉頭異常感 & 5 & 3 & 8 \\
\hline 呼吸困難 & 0 & 2 & 2 \\
\hline そ の 他 & 7 & 5 & 12 \\
\hline
\end{tabular}

表 3 訪医経路

\begin{tabular}{l|c|c}
\hline \hline 当 科初 診 & 36 例 & $40.0 \%$ \\
院外耳鼻科紹介 & 42 & 46.7 \\
院内他科紹介 & 5 & 5.6 \\
院外内科紹介 & 5 & 5.6 \\
院外外科紹介 & 2 & 2.2
\end{tabular}

耳鼻咽唉科施設よりの紹介が42例と圧倒的に多 く，他科紹介患者は12例と少数であった。

4. 術前検査所見

当科では, 注涪全例に対して頸部単純X線撮 影, CT scan, ${ }^{99 \mathrm{~m}} \mathrm{Tc},{ }^{201} \mathrm{Tl}$ scintigram を施行 し，一部の症例には ${ }^{67} \mathrm{Ga}$ scintigram を併せて 行っている. 最近の症例では, 超音波検査,

MRI も施行し，診断に用いているが，まだ少 数である.この中で特に, 石灰化像の有無, 及 び ${ }^{201} \mathrm{Tl}$ delayed scintigram の所見に関してま とめた。

表 4 に石灰化像の有無につき，悪性，良性疾 患ごとに示した。尚, 石灰化像の有無は頸部X 線単純撮影及び CT scan により確認したが, これらの検查を施行していなかった 1 例を除き 89例について検討した. 表 4 に示した通り89例 中24例 $(27.0 \%)$ に石灰化像が認められた。こ のうち, 17例が乳頭癌, 2 例が濾胞癌であり, 24 例中19例（79.2\%）が悪性疾患であった．残り の 4 例は腺腫様甲状腺腫， 1 例が乳頭腺腫であ った.

RI scintigram に関しては, ${ }^{201} \mathrm{Tl}$ delayed scintigram が悪性腫瘍の鑑別に有用であるとの 報告が多(2)4)，我々の症例では79例に対して ${ }^{201} \mathrm{Tl}$ scintigram を施行しており，そのらち， 1 時間後の delayed scan にて集積像を示した 症例は47例（59.5\%）であった（表 5 ）。29例 が乳頭癌， 3 例が濾胞癌， 2 例が扁平上皮癌で あり，47例中 35 例 $(74.5 \%)$ が悪性疾患であっ

表 4 石灰化像

\begin{tabular}{|c|c|c|c|}
\hline & 良 性 & 悪 性 & 合 計 \\
\hline 石灰化像なし & 35 例 & 30 例 & 65 例 \\
\hline 石灰化像あり & 5 & 19 例 & 24 \\
\hline
\end{tabular}

表 $5 \mathrm{Tl}$ シンチグラム (delayed scan)

\begin{tabular}{|c|c|c|c|}
\hline & 良 性 & 悪 性 & 合 計 \\
\hline 集積才 & 23 例 & 9 例 & 32 例 \\
\hline 集積あり & 12 & 35 & 47 \\
\hline
\end{tabular}


た．その他，12例が良性疾患であり，そのうち 6 例が腺腫様甲状腺腫であった。

5. 手術術式

表 6 に手術術式について示した. 手術術式の 分類については甲状腺癌取扱い規約に従った ${ }^{5}$. また，これらの手術はすべて初回手術の術式を 示している.

全摘した症例 12 例であり，そのらち 10 例 （83.3\%）は悪性疾患であった。 また，亜全摘 を行った症例は32例で，そのうち28例 (87.5\%) が悪性疾患であった。一方，良性疾患でも病変 が多発性であったり，腫瘍が巨大であったもの は，全摘（2 例），もしくは亜全摘（4例）を 行った. 葉切除を行ったものは28例であるが， 病変が小さく限局していた 8 例の悪性疾患を除 き，20例（71.4\%）が良性疾患であった。葉部 分切除を行ったものは 5 例であるが，そのらち の 2 例は呼吸困難を主訴とし, 気道確保の目的 で，部分切除とともに気管切開術を施行した未 分化癌症例と悪性リンパ腫症例で，他の 1 例は， 乳頭癌症例であるが，腫瘍の浸潤が強く，全身 的な状況から判断し, 部分切除にとどめ, 後に 放射線療法を施行した症例である。しかし，そ の他の症例はすべて良性疾患であった，核出術 は13例中12例が良性疾患に対して行われている が，これらは全て昭和61年までの症例であり， それ以降は 1 例も施行されていない，1例の悪 性腫瘍例は, 術後の永久病理診断で濾胞癌の確 診が得られ, 後日, 甲状腺全摘術を施行した症 例である。

頸部リンパ節転移が認められた23症例に対し ては，頸部郭清術が施行されたが，そのうち15

表 6 手術術式

\begin{tabular}{|c|c|c|c|}
\hline & 良性 & 悪 & 合 計 \\
\hline 全 & 2 例 & 10 例 & 12 例 \\
\hline 严 全 摘 & 4 & 28 & 32 \\
\hline 葉 切 除 & 20 & 8 & 28 \\
\hline 葉部分切除 & 2 & 3 & 5 \\
\hline & 12 & 1 & 13 \\
\hline
\end{tabular}

例は保存的頸部郭清術であり, 残りの 8 例は根 治的頸部郭清術であった. 喉頭, 食道, 気管に 浸潤していた症例に対しては拡大手術が行われ たが， 2 例は気管端々吻合術， 1 例は咽喉頭頸 部食道摘出術を併せて施行している.

\section{6. 反回神経麻痺}

嗄声を主訴として来院した患者は20例である が，その中の17例に反回神経麻痺が認められ， しかも, これらは全て悪性疾患（乳頭癌14例, 濾胞癌 1 例, 扁平上皮癌 2 例）であった。呼吸 困難を主訴とした, 未分化癌, 覀性リンパ腫各 1 例は, 両側反回神経麻痺が認められた。

術前より反回神経麻痺が認められた症例を除 き, 術後に反回神経麻痺を来した症例は 11 例 (12.2\%) 認められた。この中で 3 例は腫瘍が 神経に強く浸潤していたために，やむなく神経 を切断した乳頭癌症例である. また他の 5 例は 6 力月以内に完全回復したが，2 例は不全麻痺 を残した. 残りの 1 例は術後 4 力月目で回復傾 向にあったものの，その後の経過は不明である.

\section{考察}

甲状腺疾患に対して外科治療を行ら場合, 喉 頭, 気管, 頸部食道, 血管, 神経などの頸部の 局所解剖学的知識に熟知していることが必要で あり, 特に反回神経に対する処理, リンパ節転 移に対する頸部郭清術など，この領域に慣熟し ている頭頸部外科医が積極的に行らべき手術で あると思われる。

当科では, 昭和 51 年 11 月開院以来, 平成 2 年 12月までの約14年間に, 初回手術のみで90例の 甲状腺疾患に対して手術を行っているが，これ は全手術症例の約 $2 \%$ に過ぎない。しかし，そ の変遷をみると, 開院から昭和57年までの約 6 年間では, わずか 7 例に対して手術を行ったに 過ぎなかったものの, 昭和 58 年より急激に症例 数が増加していることがわかる.ささらに, 平成 2 年には18例の症例数に至って掞り，これは年 間手術症例数の約 $6 \%$ にあたり, 最近特に増加 の傾向にあることを示している.

ところで，患者の訪医経路を表 3 に示したが， 
これでわかるよらに当科初診及び他の耳鼻咽喉 科施設よりの紹介患者が大多数を占めており， 他科よりの紹介患者は極めて少数である．しか も，これらの患者の多くは嗄声，咽喉頭異常感 を主訴として扣り，他科で甲状腺腫瘍と診断さ れた後に当科へ紹介された患者は，全体ではさ らに少数である。しかしながら，最近では，内 科で甲状腺腫瘍と診断され当科へ紹介される患 者も徐々に増光始めており, 今後さらに症例数 が増加するものと思われる。

当科に扣ける悪性疾患例は50例（55.6\%）で あり，悪性疾患の割合が高い傾向にある。一般 に耳鼻咽喉科で扱ら甲状腺腫瘍は，覀性のもの が多いとされているが6)7)，当科の症例でも同 様であり，むしろ他の報告上り多い傾向にある。 これは, 当科の症例では, 腫瘍が気管周囲に浸 潤し，嗄声その他の耳鼻咽喉科的症状を訴え来 院する患者が多いためと, 関連病院から紹介さ れる患者は，多くが悪性腫瘍であるという，大 学病院の特殊性によるものと思われる.

主訴をみると，前頸部腫瘤を訴えて耳鼻咽喉 科施設を訪れる患者が最も多い，次いで嗄声を 主訴とする患者が多いが，この中で術前に反回 神経麻痺が認められた症例は17例であり，しか も, これらの症例はすべて悪性疾患であった。 畑山ら1) は自検例199例中17例に術前に反回神 経麻痖が認められ，我々の症例之同様に，その すべてが悪性腫瘍であったと述べて掞り，この 点に関しては，諸家の報告とも一致している4). したがって, 甲状腺腫瘍が認められた場合, 術 前の反回神経麻痺の有無は，良性・悪性を鑑別 する上で，最も重要な所見であると共に，術前 に喉頭所見を確認することは，甲状腺外科を扱 ら医師にとっては必須であると考える。

咽喉頭異常感を主訴とした患者は 8 例であっ たが，そのらち 3 例に悪性疾患が認められた。

また，甲状腺疾患に関連のない症状で耳鼻咽喉 科を受診し，頸部腫瘤を指摘された患者は 9 例 であったが，そのらち 3 例が悪性疾患と診断さ れた。咽喉頭異常感を主訴として耳鼻咽喉科外
来を受診する患者は決して少なくない、また， これらの患者に甲状腺疾患が発見されることは 珍しくなく8)，一般耳鼻咽喉科外来における， 頸部触診の重要性を改めて認識させられた。

当科では，甲状腺腫瘍の患者に対して，現在 はルーチン検査として，甲状腺ホルモン等の血 液検查, 頸部 X 線検査, CT 検査, RI scintigram，超音波検査を施行している．このなか で，頸部X線検査及び CT 検査で石灰化像が認 められた症例は24例である，一般に，石灰化像 が認められる場合には悪性腫瘍が多いとされる が9)，良性腫瘍特に腺腫様甲状腺腫にも認めら れる場合があるといら10)。乳頭癌では微細石灰 像や不規則な形の大きい石灰像が認められ，良 性腫瘍の場合には, 被膜の形に一致した滑らか な円弧状の像が認められるともいわれている10). 我々の症例では，24例に石灰化像が認められ， そのうち19例が悪性疾患であった。

ところで RI scintigram は甲状腺疾患ではよ く施行されているが，特に ${ }^{99 \mathrm{~m}} \mathrm{Tc},{ }^{201} \mathrm{Tl},{ }^{67} \mathrm{Ga}$ scintigram が重要である。 ${ }^{99 \mathrm{~m}} \mathrm{Tc}$ は甲状腺が機 能している部分に取り込まれるが，悪性・良性 の鑑別には不向きである。 ${ }^{201} \mathrm{~T} 1$ scitigram は良 性・悪性腫瘍に限らず取り込まれるために，こ れだけで悪性腫瘍を鑑別することは難しい，そ こで ${ }^{201} \mathrm{Tl}$ scintigram では, 静注10分後の early scan と, 静注 2 時間後の delayed scan の二通 りが行われ, delayed scan で腫瘍に取り込みが 認められた場合，悪性の確率が高いとされてい る4)11)12)。当科の症例では, ${ }^{201} \mathrm{Tl}$ scintigram を 施行した79例中，47例に delayed scan で集積 が認められ，そのらちの35例が悪性疾患であっ た.いずれにせよ, これらの検査単独では, 術 前に確実に悪性腫㾮の鑑別はできないが，悪性 を疑わせる重要な所見であることには変わりは ない.

甲状腺癌取り扱い規約5) に上れば，甲状腺切 除は, 全摘, 亜全摘, 葉切除, 葉部分切除, 峡 切除，核出，その他に分類されている.この分 類に従い，我々の手術術式を表 3 に示した。甲 
状腺癌における腫瘍の切除範囲に関しては様々 な意見があり，全例に全摘をすすめる意見もあ

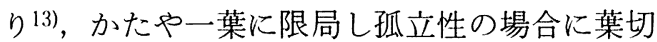
除を行い，これを最小の切除範囲にするとの意 見もある14). 当科では術中に凍結切片により迅 速病理検査をほぼ全例に行っているが，その結 果悪性腫瘍の診断が得られた場合, 腫瘍が多発 性で両側に認められる場合には，基本的には全 摘を行っている．また腫瘍が $2 \mathrm{~cm}$ 以下で限局 している症例に限っては，峡切除を含む葉切除 も行っているが，わずか 8 例に過ぎない，これ は我々の扱っている甲状腺癌は比較的大きく, 浸潤性の高い症例が多いためであり, 結局, 悪 性腫瘍の約 $80 \%$ 症例に対して全摘もしくは亜 全摘が行われているのが現状である.

河西ら ${ }^{15)}$ は, 転移率の高い気管旁, 気管前, 及び患側の甲状腺旁リンパ節の郭清を最小限行 らべきであると述べており，当科でも，これに 従い, リンパ節腫張の有無にかかわらず，気管 前，気管旁リンパ節郭清は，ほぼ全例について 行われている．頸部にリンパ節を触知した場合 には頸部郭清術が行われるが，江崎ら 14) は根 治的頸部郭清術でも治療効果の向上は得られな いため，内頸静脈，胸鎖乳突筋を温存する保存 的頸部郭清術で十分であると報告しており，最 近では当科でもこの方針に従っている.

ところで，予防的頸部郭清術の是非に関して は異論の多いところである。頸部にリンパ節を 触知しなくても転移は高率に認められるため 16$)$, 予防的頸部郭清術を施行すべきであるとの意見 もあるが，一方，その必要はないとの報告もあ

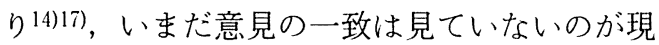
状であろう。当科では気管旁, 気管前リンパ節 の郭清は行っているが，予防的頸部郭清術は施 行していない，現在までのところでは，特に再 発率が高いとは言えないが，この点に関しては 今後の検討が必要であろら。

甲状腺手術において，術後合併症に関して最 も問題にされるのは, 術後の反回神経麻疩であ る. 当科の症例では 11 例に術後反回神経麻疾が
認められたが，そのらちの5例は一過性麻痺で あった。経過不明 1 例，腫瘍が浸潤していたた めにやむなく神経切断した 3 例を除けば，未回 復なものはわずか 2 例のみであり，永続的な麻 痺を残した症例は極めて少ないものと思われる。 甲状腺手術においては，反回神経の走行を確認 することは当然である，その際には，神経を愛 護的に扱らことが重要であり ${ }^{18)}$ ，仮に術後に麻 痺を来しても，切断さえしなければ，一過性で あり大きな問題にならないものと思われる.

\section{まとめ}

1. 昭和51年11月開院以来14年間で，90例の 甲状腺手術を施行し，それらの症例に対して臨 床的考察を加えた。

2 . 悪性疾患 50 例, 良性疾患 40 例で悪性疾患 の方が多い傾向にあった.

3. 主訴としては, 頸部腫瘤が最も多く, 次 いで嗄声が多かった，尚，19例に術前に反回神 経麻㽻が認められたが，それらはすべて悪性疾 患であった。一方，咽喉頭異常感を主訴とした 8 例のらち 3 例に悪性疾患が認められた。また， 耳鼻咽喉科外来診察時に甲状腺腫瘤が発見され た 9 例のらち 3 例に悪性疾患が認められ，一般 耳鼻咽喉科診察における，頸部触診の重要性を 改めて認識させられた。

4. 悪性疾患のらち約 $80 \%$ の症例では，全摘 もしくは覀全摘が行われていた。また，ほとん どの良性腫瘍では, 葉切除が行われていた。

5. 悪性疾患では原則的に, 気管旁, 気管前 リンパ節郭清が行われた．頸部郭清術はリンパ 節腫張が認められた症例に対して行われ，予防 的頸部郭清術は行わなかった。

6. 術後の反回神経麻瘴はほとんど一過性で あり，注とんどは 6 力月以内に回復し，未回復 であった症例はわずか 2 例であった。

\section{文献}

1）畑山尚生, 熊井恵美, 白戸 勝, 他 : 当科飞未 ける甲状腺疾患の臨床的統計.耳鼻臨床 補15： 103 109, 1987.

2）立川拓也, 友田幸一, 山下敏夫, 他 : 甲状腺疾 
患の統計と画像診断の有用性一 5 年間の症例を 中心に一. 耳鼻臨床 $81: 1779 \sim 1787,1988$.

3）吉田 康, 川浪 貢, 飯塚桂司：当科に拈ける 甲状腺腫瘍症例の臨床的検討.耳鼻臨床 82 ： 429 436, 1989.

4) 熊井恵美, 畑山尚生, 高橋光明, 他 : 甲状腺腫 瘍の術前診断一 ${ }^{201} \mathrm{Tl}$ delayed scintigram を用 いた検討一. 耳鼻臨床 補15：110～114, 1987.

5) 甲状腺外科検討会: 外科, 病理. 甲状腺癌取扱 小規約（第 2 版）。金原出版，東京， 1983 .

6) 佐藤文彦, 斎藤 等, 水越 治: 甲状腺癌の臨 㦿的考察. 日耳鼻 $74: 1482 \sim 1495,1971$.

7）中村昭郎, 小山 弘：甲状腺癌の実態おょび臨 床的考察. 耳鼻臨床 $68: 711 \sim 721,1975$.

8）戸田雅克, 北野康雄, 太田文彦：甲状腺疾患之 咽喉頭異常感.耳鼻臨床 補23：104 109, 1988.

9）樋口公明：悪性甲状腺腫の診断と治療成績. 医 療 $23: 10 \sim 25,1969$.

10）金澤曉太郎, 岸田敏博, 伊藤紘一, 他：甲状腺 の臨床診断. 手術 $41: 3 ; 317 \sim 329,1987$.

11）沢久, 福田照男, 伊丹道畺, 他: ${ }^{201} \mathrm{TlCl}$ による甲状腺癌鑑別の可能性一特に delayed scintigraphyによる検討一. 核医学 $15: 1223$ 1227, 1978.

12）田中治, 松永喬, 宮原裕, 他: 甲状腺腫
瘍における ${ }^{201} \mathrm{Tl}$ シンチの意義. 耳鼻臨床 84 ： 83〜87, 1991.

13) Russel WO, Ibanez ML, Clark RL, et al : Thyroid carcinoma. Cancer $16: 1425 \sim 1460$, 1960.

14）江崎治夫, 伊藤利夫 : 甲状腺乳頭癌手術法に関 する controversy と手術手技. 手術 41:3；367 $\sim 375,1987$.

15）河西信勝, 内田正興, 篠崎 登, 他: 甲状腺癌 の手術 local (neck) dissection について. 手術 $33: 1195 \sim 1199,1979$.

16）河西信勝, 細谷哲男, 野口明彦, 他: 甲状腺分 化癌 N0, pN0 症例に打㺭る病理組織学的リン ＜compat>節転移. 癌の臨床 $28: 785 \sim 788,1982$.

17) Block MA, Miller JM and Brush BE : Place of radical neck surgery in thyroid carcinoma. Arch Surg 78 : 706 713, 1959.

18) Matthew JL, Larry AH and Lionel $Z$ : Surgical strategy in thyroid disease. Arch Otolaryngol $116: 1378 \sim 1383,1990$.

$$
\left(\begin{array}{l}
\text { 別刷請求先 : 中村 正 } \\
\text { 干990-23 山形市飯田西2-2-2 } \\
\text { 山形大学医学部耳鼻咽喉科学教室 }
\end{array}\right)
$$

